John Carroll University

Carroll Collected

2019

The future of employee development

Alison Dachner

Jill E. Ellingson

Raymond A. Noe

Brian Saxton

Follow this and additional works at: https://collected.jcu.edu/fac_bib_2019

Part of the Business Commons 


\section{The future of employee development}

Keywords:

Employee development

Employee-driven development

Human capital development

Proactive behavior
A series of trends shaping the current workplace has changed the nature of human capital development practice to be more employee-driven. However, existing development research does not fully account for this shift and the anticipated benefits of employee-driven development. In this review we reflect on the current state of the employee development literature and propose a new, broader conceptualization of employee development characterized by a partnership between the employer and employee. In doing so, we offer three recommendations for how research needs to evolve to align employee development scholarship with current practices: (1) incorporate proactivity in the definition of employee development, (2) update the context for learning, and, (3) think differently about how human capital is valued. We suggest ways in which theory can be extended for increasing our understanding of several commonly used employeedriven development methods. Finally, we provide future research questions and practical suggestions based on our new conceptualization of employee development.

\section{Introduction}

Human capital is an essential component of individual career advancement and organizational competitive advantage (Barney \& Wright, 1998; Ployhart, Nyberg, Reilly, \& Maltarich, 2014). Increasingly valuable to employees and firms, the development of knowledge, skills, and abilities that provide economic value to an organization constitutes a critical talent management initiative. Indeed, both C-suite executives and human resource (HR) professionals emphasize that developing the necessary skill set within the next generation of leaders is a top human capital challenge for organizations operating in a global, knowledge-based economy (PricewaterhouseCoopers, 2016; SHRM, 2015). Accordingly, most organizations invest in training and development programs as part of HR strategy.

Employee development involves "the expansion of an individual's capacity to function effectively in his or her present or future job and work organization" (McCauley \& Hezlett, 2001, p. 314). Development activities include formal education, job experiences, professional relationships, and assessment of personality, skills and abilities that help employees grow professionally (Noe, Clarke, \& Klein, 2014). Formal development programs include classroom instruction, on-line courses, college degree programs, and mentorship programs, systematically designed with specific goals, learning objectives, assessment instruments, and expectations (Chen \& Klimoski, 2007). The general belief in the literature has been that these types of programs will produce employees capable of fulfilling human capital needs. There have been a number of excellent, comprehensive reviews which look back over the course of employee 
development research and reflect on the construction and effectiveness of traditional, formal programs (e.g., Bell, Tannenbaum, Ford, Noe, \& Kraiger, 2017; Chen \& Klimoski, 2007; Garofano \& Salas, 2005; Jacobs \& Park, 2009). These reviews leave little doubt that formal employee development programs are valuable for facilitating meaningful employee growth.

However, the traditional perspective that development takes place at the discretion of the employer with an instructor carrying out carefully designed development plans in service to employer goals limits our ability to understand how employee development happens today. We believe it is time for scholarship to embrace a broader, more up-to-date conceptualization of employee development. As we will describe, a series of economic and job related trends have eroded the employer's willingness to invest in general human capital. Employees are expected to take more responsibility for enhancing current skills and adding new ones to meet current job demands, prepare for leadership opportunities, and ensure their own employability to move and adapt within and between organizations as needed (Molloy \& Noe, 2010). Moreover, about 35\% of employee training and development hours in organizations now occur in the absence of an instructor (ATD, 2016). This has substantially altered the types of activities employees engage in to develop themselves. Hours are increasingly devoted to informal, unstructured and innovative methods of development that emphasize learner autonomy and learner-driven interaction such as job crafting, communities of practice, webinars, Massive Open Online Courses (MOOCs), and social media exchange (Barnes, Lescault, \& Wright, 2013; McFarland \& Ployhart, 2015; Ravenscroft, Schmidt, Cook, \& Bradley, 2012).

For example, Mindtree Limited, a global company in the information and telecommunications industry, created its own social networking and knowledge sharing platform, called Konnect, which includes blogs, discussion forums, wikis, podcasts, videos, document repositories and social bookmarking (Salopek, 2015). Employees can like, share, and recommend content for the purpose of developing themselves and others. Hilton Worldwide encourages employees to use Twitter, Facebook, YouTube, and Instagram and provides company-specific portals such as "the Lobby" which allows employees to share and learn through best practices (Harris, 2015). Evans Analytical Group, a high-tech analytical services company, uses social media to connect its globally-dispersed employees and reduce the time it takes employees to locate subject matter experts (Thomas, 2015). Employees are encouraged to use Twitter, LinkedIn or the company intranet to locate information and knowledge resources for learning and problem-solving on the job.

New development methods provide access to growth opportunities anytime and anywhere. The implication for talent management is that organizations may support and encourage learning, but rely on employees to serve as their own talent agents by taking advantage of opportunities and seizing the role of life-long learner. The lifelong learning literature emphasizes that it is essential for individuals to enhance their personal, social, and career development by enriching their knowledge, skills, and competencies throughout their lifespan (London, 2011). Individuals need to be motivated to learn and the organization needs to provide the necessary culture and resources that empower individuals to learn. In their discussion of emerging conceptualizations of adult learning, Bedwell, Weaver, Salas, and Tindall (2011) emphasize that technological and demographic, as well as changes in the employment relationship, mean lifelong learning will increasingly involve opportunities that employees seek on their own rather than attending formal mandatory programs sponsored by the organization.

To align with current practice, scholarship needs to adopt the perspective that development is a shared responsibility between employers and employees. The focus of development scholarship must evolve from an ego-centric view that the employer knows best to recognizing the importance of the employee's entrepreneurial spirit. Rather than passively waiting for organizations to assess, structure, and institute development, employees must view the organization as a development resource and take an active role in developing themselves.

The purpose of this review is to reflect on the current state of the employee development literature and propose how scholarship needs to evolve to better represent employees as active talent agents. We begin by briefly reviewing the evolution of classic employee development research and theory. Following this discussion, we detail three recommendations for evolving the development literature toward models that better align with current practice. Current development research depends almost exclusively on theories of learning and motivation. However, recognizing employees as entrepreneurial in their own development suggests that greater insights can be realized by incorporating theories related to proaction and human capital. Further, the literature must focus more on understanding the antecedents and consequences of employee-driven, dynamic, technology-enabled activities that facilitate employee adopting an entrepreneurial approach to development.

Our recommendations emerge from this position and outline why it is important to broaden our conceptualization of development and the frameworks we use to understand it, as well as how this can be supported by research. The first recommendation describes the role of the employee as an active agent based on key parameters of the theory of proactivity and thus, outlines the need to incorporate proactivity directly into the definition of employee development. The second recommendation is to update the context for learning by considering the various firm- and job-related trends influencing the modern workplace and how people learn and develop. The third recommendation illustrates the importance of using human capital theory to change the way human capital is viewed and valued by embracing mutual investments in both general- and firm-specific human capital. Then, we use Noe, Wilk, Mullen, and Wanek's (1997) four-dimension taxonomy of developmental experiences as an organizing framework to further illustrate how contemporary development methods exemplify these recommendations. This taxonomy is well-known, and commonly used in textbooks, research, and practice to categorize employee development experiences into four components: employee assessment, on-the-job experience, professional relationships, and formal courses or programs. The taxonomy allows us to capture and meaningfully classify a wide-range of contemporary learning and development activities as they occur in organizations (Hurtz \& Williams, 2009; Jehanzeb \& Mohanty, 2018; Noe, 2017; Noe et al., 2014) while explaining how the three recommendations emerge in development practice today. Finally, we propose a series of questions to guide future employee development research. 


\section{Classic employee development research and theory}

Research on employee development originated with the view that development is an episodic, organization intervention intended to facilitate or directly develop job-relevant knowledge and skills (Hurtz \& Williams, 2009). Research on systematic models of instructional design (Gagne, 1962; Goldstein, 1986) flourished, with a primary focus on identifying method and design variables that predict learner success (Bell et al., 2017). Theories of behavioral psychology such as reinforcement theory (Skinner, 1953), and cognitive psychology such as social learning theory (Bandura, 1977), were at the forefront of learning theory and research focused on testing the efficacy of interventions (Kraiger \& Ford, 2007).

Development research evolved when researchers emphasized the role of constructivist theories of learning on instructional design. Constructivism asserted that learning is an active, social process in which the learner constructs their own knowledge from their own experiences (Kraiger, 2008). Constructivism stressed that learning varies across individuals even if they experience the same development opportunities (Morrison \& Brantner, 1992). Accordingly, research emerged with a focus on documenting how various individual differences influence learning outcomes. For example, general mental ability (GMA), goal orientation, and motivation to learn were identified as critical individual difference variables that influence the outcome of training and development interventions (Baldwin \& Ford, 1988; Dweck, 1986, 1989). Studies eventually took a broader approach to employee development by viewing it as an ongoing, continuous process consisting of activities that could be voluntary or mandatory, formal or informal, related either to one's current job or to long-term personal effectiveness, and engaged in either during or outside of work time (Noe et al., 1997; Noe et al., 2014).

The 21st Century brought greater interest in understanding how to promote and enhance voluntary employee development through easier access to such opportunities (e.g., Hurtz \& Williams, 2009). For example, research has sought to answer questions concerning formal development initiatives delivered through e-learning rather than traditional classroom learning (Schmidt \& Ford, 2003; Sitzmann, Kraiger, Stewart, \& Wisher, 2006). Also, recent research continues to examine how employees learn from job experiences (e.g., Billett, 2001; Courtright, Colbert, \& Choi, 2014; Dragoni, Oh, Vankatwyk, \& Tesluk, 2011; Eby, Butts, Hoffman, \& Sauer, 2015; McCall, 2004), assessments (e.g., Noe, 2017; Smither \& Walker, 2004), and mentoring and coaching (e.g., Allen, Eby, Chao, \& Bauer, 2017; Allen, Eby, Poteet, Lentz, \& Lima, 2004; Payne \& Huffman, 2005).

Development research has begun to acknowledge the active role of the learner (rather than the trainer) in creating an effective environment for learning (e.g., Bell et al., 2017; Krager, 2008; Tannenbaum, Beard, McNall, \& Salas, 2010). However, it has been slow to recognize that learner's responsibilities now extend beyond the scope of attending a specific program or class. Thus, although recent research has "moved us closer to a theory of learner-centered training design" (Bell et al., 2017), current development theories and frameworks fall far short of positioning employees as active investors who must proactively manage their personal human capital development using contemporary methods.

\section{Advancing employee development theory and research}

Future employee development research needs to evolve to think differently about how employees develop and how employers should support that development. To facilitate this transformation, we offer three recommendations based on the theory of proactive behavior, human capital theory, and several trends in the modern workplace.

\subsection{Incorporate proactivity in the definition of employee development}

The current context for development emphasizes that employees must be proactive in directing their own learning and growth. The Society for Human Resource Management (SHRM), the primary professional organization for HR professionals, takes the position that development must be employee-driven such that employees need to actively identify personal skills needs, pursue development opportunities, and manage their own careers with or without an organization investment (Fugate, Kinicki, \& Ashforth, 2004; SHRM, 2009; Sullivan \& Baruch, 2009). In short, they need to be proactive in their development.

Proactive behavior refers to initiating and creating change by taking control of a situation for the purpose of removing uncertainty and ambiguity, rather than passively adapting to present conditions (Crant, 2000). Proactive behavior is grounded in theories of motivation, as individuals who are proactive have to self-regulate and choose to devote effort and attentional resources toward setting and achieving goals autonomously (Parker, Bindl, \& Strauss, 2010). According to the theory, this choice to proceed autonomously is reinforced by the expectation that self-initiated, anticipatory action can produce a more favorable work situation for oneself in the future (Griffin, Neal, \& Parker, 2007; Parker et al., 2010; Parker, Williams, \& Turner, 2006). Proactivity is important for enhancing employee performance and career advancement (Fuller, Fuller Jr., Kester, \& Cox, 2010; Seibert, Kraimer, \& Crant, 2001; Seiling, 2001; Thompson, 2005).

Incorporating these ideas into the definition of employee development results in a broader characterization that encompasses four principles, as identified in Fig. 1. Proactive employee development means employees take the initiative to anticipate skill needs by actively soliciting feedback from managers and/or mentors well in advance of formal organization assessment. They identify and take advantage of options to fulfill those needs in order to perform successfully on the job. Proactive employee development means employees create opportunities for growth, holding themselves accountable for their own careers versus passively waiting for opportunities to be created for them. They are reinforced in seeking growth because they recognize the benefits that proactive development brings for advancement and improving their work environment.

Adopting proactivity as an explicit component of development will help expand what is considered developmental action and 


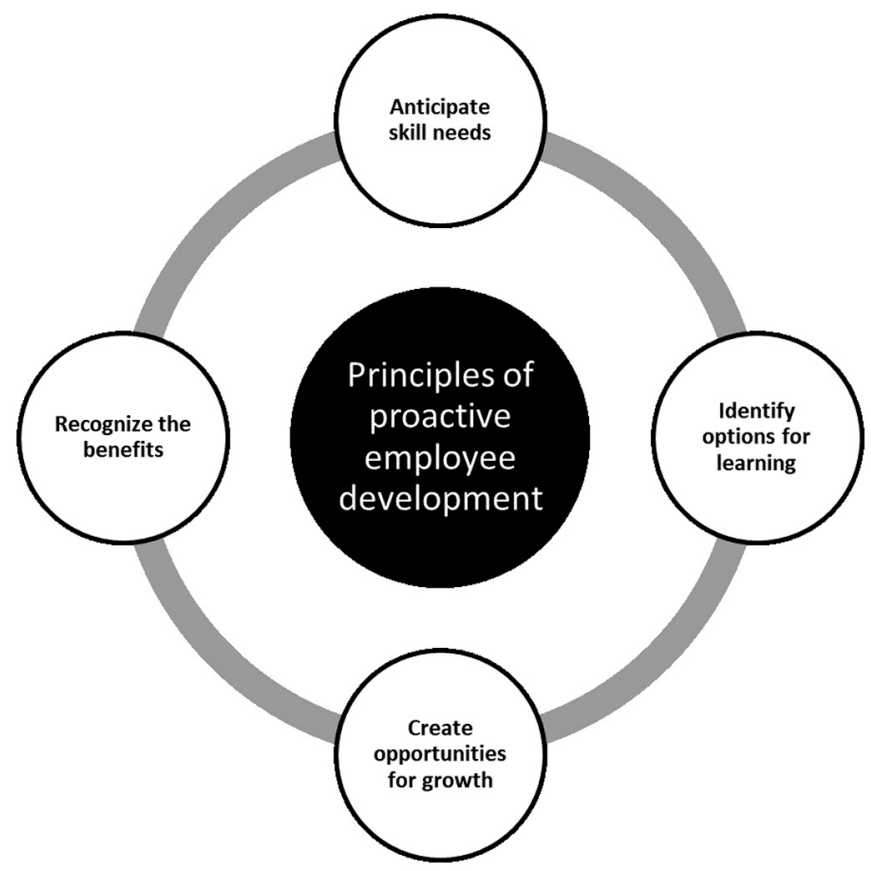

Fig. 1. The principles of proactive employee development.

facilitate a more contemporary understanding of how development occurs and its associated outcomes. As is the case for other proactive behaviors, proactive employee development is likely influenced by the extent to which individuals feel capable of learning ('can do'), whether they have a purpose to engage in learning ('reason to'), and whether they have the positive affect necessary to learn ('energized to') (Parker et al., 2010). These elements of needing to feel capable, sufficiently motivated, and energized imply that individual differences are poised to profoundly affect proactive employee development, more so than traditional development which tends to motivate and induce efficaciousness through instructional design. For example, individuals with high levels of learning agility and/or PsyCap may be more capable of maintaining the psychological energy needed to engage in and sustain involvement in proactive development activities. Learning agility refers to an individual's willingness or ability to learn from experience (DeRue, Ashford, \& Myers, 2012). PsyCap represents a positive psychological state of development. It is characterized by having confidence (self-efficacy), making positive attributions (optimism), persevering toward goals in the expectation of success (hope), and sustaining energy (ego resilience) even in the face of adversity (Luthans, Youssef, \& Avolio, 2007). An individual's degree of learning readiness, which includes goal orientation, curiosity, and need for cognition, will likely affect the extent to which employees are able and willing to take advantage of proactive learning opportunities (Cerasoli et al., 2018; Ellström, 2001; Rigolizzo, 2019). While obvious, it also bears noting that proactive personality should be integral to proactive employee development. Proactive personality refers to the disposition, or relatively stable tendency, of individual's to take action to influence their environment (Bateman \& Crant, 1993; Major, Turner, \& Fletcher, 2006; Thompson, 2005). Such individuals would be expected to have the initiative, determination and perseverance to actively manage their development (Antonacopoulou, 2000; Crant, 2000; Major et al., 2006).

Proactive employee development may also be related to a broader set of outcomes compared to traditional development activities. For example, the self-initiated, discretionary nature of proactive development may lead to increased stress, anxiety and burnout for some employees (Noe et al., 2014). Alternatively, the autonomy associated with proactive development may relate to enhanced feelings of personal control and influence employee work-life balance, outcomes not typically examined in development research.

\subsection{Update the context for learning}

Research on formal development programs demonstrates that context (e.g., managerial support and work characteristics) matters for learning. The shift to proactive employee development where learning is self-initiated and often accomplished in conjunction with executing work tasks implies that contextual factors now have an even more important influence (Parker et al., 2006). A series of firm- and job-related trends have reshaped the environment for work and hence, the context for learning. The first trend is a shift in job design from steady and routine tasks to more complex, dynamic tasks (Harrison, Johns, \& Martocchio, 2000). Employees are relying more heavily on creative-thinking and problem-solving strategies to complete non-routine, unpredictable work tasks (Reinhardt, Schmidt, Sloep, \& Drachsler, 2011), and often face time constraints associated with the immediacy of new competency requirements. Second, employees must deal with increasing work demands including longer hours, more travel, and more responsibility. These factors reduce the time employees have available to participate in formal development programs despite the need to enhance current or acquire new skills (SHRM, 2012). 
A third trend is the continued flattening of organizational structures toward horizontal designs that afford less opportunity for upward mobility (Mohrman, Cohen, \& Mohrman Jr., 1995). The absence of promotional opportunities suggests "an increased focus on finding alternative ways for employees to develop their careers and continue to learn" (SHRM, 2012). The fourth trend is the increased use of advanced technology in the workplace. One of the top HR trends in the past several years has been that employees often complete work offsite or telecommute and interact with managers, peers, and customers through social networking involving instant messaging, discussion boards, social media, video conferencing, and email (e.g., SHRM, 2012). Social networking, and technology in general, provide unique information sharing opportunities for employees that can facilitate learning through technology-enabled social exchange.

Finally, it has become more common for individuals to 'job-hop' between positions that require learning new knowledge and skills. According to the Bureau of Labor Statistics, individuals have roughly nine different jobs between the ages of 18 and 32 (Schawbel, 2012). In fact, current career paths, especially for millennial employees, involve a greater tendency to change not only jobs, but also organizations, industries and occupations as employees seek more competitive skill sets, development opportunities, and better jobs (Deloitte, 2017). Career ladders now cut across firms with rungs determined by personal goals, relationships, preferences, and interests, a phenomenon referred to as a "kaleidoscope" career (Cabrera, 2007; Sullivan \& Baruch, 2009). The pressure to perform well as a platform to climb to the next rung requires the ability to learn quickly. Employees must be resourceful and creative in finding information and solving work problems on their own.

These five trends combine to produce a work environment where employee development is extraordinarily complex to achieve through formal training and development practices. When skill and knowledge requirements change quickly and regularly, it becomes difficult to meet learning needs through traditional programs that require enough stability to permit specifying instructional objectives and compiling instructional activities. Furthermore, post-secondary degrees, historically viewed as investments in critical career skills and knowledge, now have a limited shelf life. Although there is evidence for the long term value of college degrees (Newton, 2018), the question is increasingly being asked, "are college degrees worth it" (Ruppel Shell, 2018; Tharp, 2018). When work is dynamic, degrees may no longer match market needs which makes continuing education through proactive employee development increasingly important for employee marketability. Further, the learning context is an essential component of understanding and applying development material (Brown, Collins, \& Duguid, 1989), yet traditional classroom-based programs rarely embody the shift to a virtual context for work (Cascio, 2014). Thus, traditional programs alone are insufficient to ensure organizational and individual readiness (Tannenbaum et al., 2010). Employees must learn more, at a faster pace, and be prepared to unlearn, relearn, and adapt their knowledge as work requirements dictate.

Additionally, the five trends necessitate an increased emphasis on ongoing and just-in-time learning through flexible and creative tactics. For example, job design features such as control, autonomy, and the social and relational aspects of work likely now play a key role in the extent to which employees are able to initiate learning activities and the type of employee development they choose to engage in (Parker, 2017). A more realistic view of how the work environment influences employee development is provided by how we conceptualize the context for learning. Factors such as interruptions, the form of interaction, job-type, and time available play a key role in whether development opportunities ultimately translate into improved or new skill sets that meaningfully enhance employee performance. Also, there is the possibility that unlike organizationally sponsored or endorsed development activities, selfinitiated learning sources (e.g., peers and websites) may provide incorrect or incomplete knowledge (Telford, Fletcher, \& Bedwell, 2017), particularly if factors such as time-pressure inadvertently encourage reliance on a limited number of activities or only sources of knowledge that are immediately accessible (e.g., social media posts) or familiar (e.g., coworkers). In summary, development research needs to better account for the fact that development effectiveness is largely contingent on a constellation of new contextual factors that characterize the current workplace.

\subsection{Think differently about how human capital is valued}

In the last fifteen years, organization strategies for managing firm-level talent needs have changed significantly (Campbell, Coff, \& Kryscynski, 2012; Coff \& Kryscynski, 2011; Ployhart et al., 2014). Historically, talent management centered on fostering vibrant internal labor markets by cultivating lush talent pipelines. A firm would identify deficiencies between the knowledge, skills, or competencies employees possessed and those the organization needed. Because jobs were steady, even routine, with tasks executed within predictable parameters, deficiencies could be forecast well in advance. HR professionals then created, designed, and implemented formal programs to address those needs. Programs were linked to promotions and job security to reinforce organization membership (Cappelli, 1999; Rousseau, 1995). Employees responded with a commitment to stay, sometimes for their entire career, allowing the organization to reap the benefits of its human capital investments.

In contrast, the exchange relationship between employers and employees is different today. Career success is now defined independent from any one organization (Gowan, 2012). Gone are the days of working for the same employer throughout one's career, and with that, the external labor market is the predominant source for human capital. The certainty that both firms and employees needed to justify investments in internal labor markets has diminished (Cappelli, 2008) leading to questions about who is responsible for investing in human capital and who should guide such investments.

Under the new employment model, employers and employees share the responsibility for human capital development. Although organizations no longer serve as sole overseer, they must still provide developmental resources and invest in human capital growth in order to sustain a competitive advantage (Barney \& Wright, 1998). Yet, how can firms capture value from employee-driven investments in human capital? The answer may lie in rethinking how human capital is valued by questioning the classic distinction between firm-specific and general human capital that underlies traditional development. Beckerian theory (Becker, 1964) predicts 
that, to the extent that employees control their own investments in human capital, general human capital (i.e., human capital that is applicable across a wide variety of employers) will become over-invested, and firm-specific human capital will become underinvested, from the employer's perspective. This is because employees will favor investing in knowledge and skills that are usable by many potential employers so they can appropriate the value of their investment within the labor market through bargaining for higher wages (Becker, 1964; Campbell et al., 2012).

However, recent work suggests that the development of general human capital can constitute a viable investment opportunity for organizations. For example, to the extent that the shift to employee-driven development practices is not isolated within a firm, occupation, or industry, supporting these practices is unlikely to put any one employer at a competitive disadvantage (Chadwick, 2017). Also, a significant part of the performance-enhancing effect of experience is embedded in and inseparable from the social context in which that experience is gained (Campbell, Saxton, \& Banerjee, 2014; Groysberg, Lee, \& Nanda, 2008; Huckman \& Pisano, 2006). If general human capital is not as "general" as it seems, then organizations can indeed benefit from supporting its development through contemporary development methods. In addition, firms may choose to support the development of employees who possess idiosyncratic bundles of human capital (i.e., groups of skills that are individually applicable across a wide variety of firms, but rarely coupled in the same way). While the skills are general, their bundled nature makes them more valuable within the current employer then they would be elsewhere (Lazear, 2009). From the employees perspective, the development of firm-specific human capital can constitute a viable investment opportunity. Firm-specific human capital is visible outside the firm and serves as a marketable signal to the labor market. For example, if an employee is willing to invest in understanding a firm's custom knowledge management system, the investment is firm-specific but the willingness to learn that is evidenced by the investment represents a characteristic that is universally valued. This enables the employee to appropriate part of the value associated with firm-specific investments even if they no longer reside within the firm (Morris, Alvarez, Barney, \& Molloy, 2017). Thus, both employer and employee stand to benefit from a partnership investment in both types of human capital.

These insights from the human capital literature have important implications that enrich development theory. First, thinking differently about how human capital is valued will help refine theory on the antecedents of the motivation of employees to invest (i.e., pursue proactive employee development activities) and the methods employers can use to motivate that investment. Even with the assumption that employees will only engage in development to the extent that they stand to tangibly benefit from it, employers should still support employee-driven development since its value is reasonably shared between both parties. In addition, research that seeks to model the relationship between development and individual and firm benefits as a function of the degree of investment should focus not only on the monetary cost of development and the increase in productivity, but also the potential for individuals who participate in development to capture value from the organization through higher compensation and the ability to compete for more advanced jobs.

\section{Employee-driven development methods}

Employee development methods fall into four categories: formal courses or programs, assessment, professional relationships, and on-the-job experience (Noe et al., 1997). We use these categories as a framework for illustrating how contemporary development methods embody proactivity, an updated work context, and new thinking about the valuation of human capital. As shown in Table 1, for each category we present specific examples of contemporary development behaviors that build human capital but are largely absent from current development research. It is important to note that the list is not intended to be comprehensive and each example may not be appropriate or possible for employees in all jobs because of factors such as job design or resource constraints. It is merely demonstrative to emphasize the importance of moving toward a broader theoretical conceptualization of what constitutes employee development and the environment within which it occurs.

\subsection{Formal courses and programs}

Seeking out and enrolling in online courses and webinars constitute autonomous development activities that employees can use to enhance their skills and knowledge. Massive open online courses (MOOCs) emerged from the academic educational resources movement. These learning experiences are open by being accessible to anyone with an internet connection and massive with the intent of enrolling thousands of students. The online learning environments incorporate videos of lectures, and interactive course work through discussion groups and wikis. The courses have start and completion dates, and include quizzes and exams (Belkin, 2014; Fowler, 2013a, 2013b). MOOCs covering a wide range of topics including computer science, psychology, physiology, and health policy have been established by several universities (e.g., Michigan, Stanford, Princeton). Courses are often developed in partnership with companies that have academic ties such as Coursera, edX (a non-profit company founded by Harvard and MIT), or Udacity (a forprofit company founded by a Stanford University professor and founder of Google X Labs). Several companies, including AT\&T, Yahoo and Starbucks, have developed MOOCS internally or in collaboration with others (Lee, 2014). For example, Georgia Tech, Udacity, and AT\&T created a MOOC that offers a master's degree in computer science (Maxey, 2017). Udacity and AT\&T also created MOOCs for nanodegrees that provide AT\&T programmers the opportunity to take courses in high-technology specializations such as software engineering, coding, or web development (Donovan \& Benko, 2016).

Webinars refer to live seminars, presentations, lectures, or workshops conducted online. Webinars provide synchronous (realtime) learning (Romiszowski \& Mason, 2004). Expert instructors transmit video, audio, and images, and encourage participants to pose questions and comments to a messaging board. There are real-time question-answer sessions, opportunities for discussion and immediate feedback, and participants can record content for review or to share with others (Wang \& Hsu, 2008). Webinars offer the 


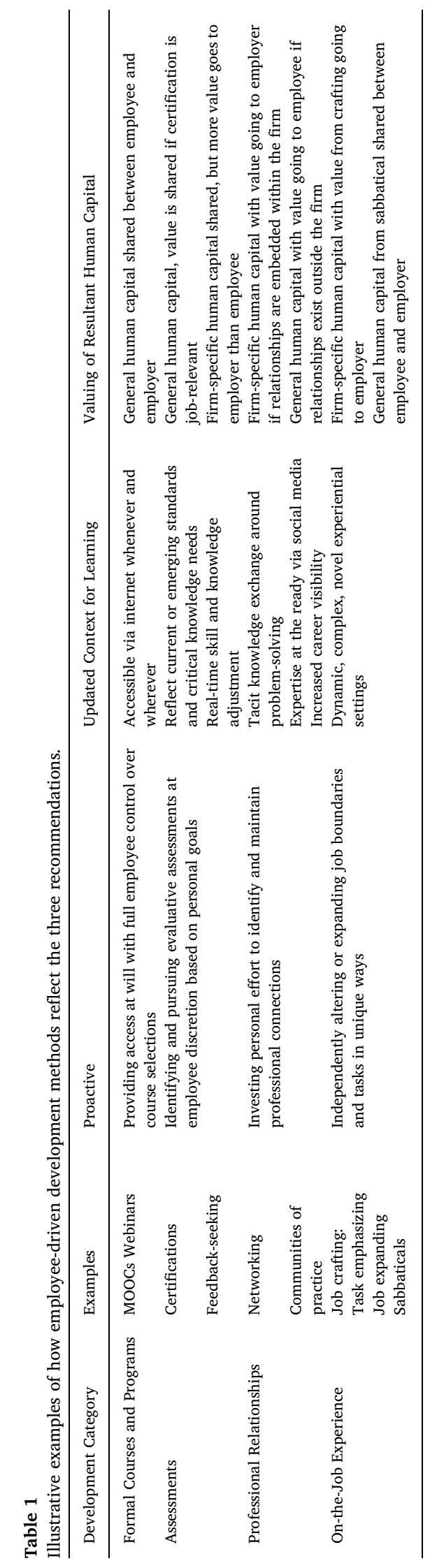


instructional properties of regular face-to-face seminars or conferences, but without the cost of travel or venues. Webinar participants may all be in one location or spread out geographically. Various professional associations offer webinar series. For example, SHRM hosts webinars on best practices for talent management and attraction; SAS hosts a series of seminars on big data and data analytics; Harvard Business Review regularly offers webinars on a variety of management, strategy, and information technology topics.

MOOCs and webinars exemplify our broader conceptualization of employee development. Because MOOCS and webinars are typically offered by an outside company, educational or training institution, employees can use these activities for development on their own terms, without waiting for supervisor or HR approval. Unlike traditional curricula, employees retain full control over their course selections and can choose MOOCs and webinars that they believe best meet their development needs and interests. MOOCs and webinars are suitable for the changing context of learning. They offer flexibility in when, how, and where learning occurs. They are accessible from wherever the employee happens to be, are entirely compatible with the needs of telecommuters or those working off-site, and their largely asynchronous design makes them manageable for employees that travel extensively or face other types of schedule constraints. In contrast to accredited degree programs or corporate programs, barriers to entry are low. Employees can access a MOOC or webinar at their discretion without financial assistance from an employer or significant, personal out-of-pocket costs. However, should the organization offer financial assistance it will likely appropriate at least some value from the skills and knowledge that result, particularly if such skills require the use of complementary assets (e.g., proprietary tools or applications). For example, if an employee learns to use a software application that is not widely used by the firm's competitors, the firm will make use of the general human capital better than rivals could (Chadwick, 2017). Further, research suggests that when organizations provide financial support for employees to participate in MOOCs, the course completion rate is higher and participating employees are less likely to look for alternate employment (Hamori, 2018). Thus, both employee and organization benefit and share the resultant value (Klein, Crawford, \& Alchian, 1978).

\subsection{Assessments}

Completing certifications and engaging in feedback-seeking are autonomous assessment activities that employees can use to upgrade skill sets and identify ways to position themselves for better performance and future opportunities. Certifications represent an assurance of one's knowledge, experience, and skills in a particular professional area. Typically, an accredited institution or professional society offers an exam for people who meet the minimum qualifications (e.g., education and years of experience) to assess their understanding and ability to perform a specific job or task. Individuals who score above the prescribed standards receive certification as proof of expertise. For example, HR professionals can earn their Professional in Human Resources (PHR) or Senior Professional in Human Resource (SPHR) from the Human Resource Certification Institute (HRCI) to signify mastery of HR (HRCI Certification: Overview). Other examples include Certified Analytics Professional (CAP) and Leadership in Energy and Environmental Design (LEED), a green building certification that identifies business owners as being environmentally responsible.

Feedback seeking occurs when employees actively inquire about their work performance or observe others and infer their strengths and weaknesses based on those comparisons (Ashford \& Cummings, 1983). Feedback-seeking is an established theory within the organization behavior literature, but is gaining new prominence as a proactive behavior (Parker \& Collins, 2010). When employees seek feedback, they take the feedback received and reflect on their strengths and weaknesses, seek advice in response to their reflection, and identify an action plan for obtaining new knowledge and skills. For example, some organizations are using apps that encourage employees to ask for and receive real-time, open, anonymous feedback. GE developed an app called "PD@GE” which stands for "performance development at GE". Employees can give or request feedback at any moment using this app (Bersin, 2015). In this way, employees gain information that allows them to identify their strengths and weaknesses, which positions them to develop in a way that improves job performance.

Feedback-seeking and certifications exemplify our broader conceptualization of employee development. Like MOOCs and webinars, certifications are offered by an institution other than the current employer. Employees may receive support from an employer to prepare, register, and pay for these assessments, but they may also independently pursue certification. These assessments also provide employees with complete control over when, how, and what certification they choose to pursue. This allows them to pursue specific certificates that align with their personal schedule and career goals, even if such certificates have yet to be specified within a formal development plan. The administrative bodies that oversee certifications revise exams as needed to make sure assessed knowledge and skills are up-to-date. Thus, in order to earn discretionary, professional certifications employees must refine, update, and augment their knowledge base, which assists in meeting the requirements of an ever-changing work environment. Certifications build general human capital, but do so imperfectly. Certifications demonstrate a commitment to succeeding and growing within a field and signal to the labor market that the employee possesses general knowledge and skills useful elsewhere. However, uncertainty often remains around the ability of the employee to use the knowledge they gained outside their current position, and this knowledge asymmetry may limit the employee's options on the labor market. When the knowledge gained from the certifications is most relevant to one's current position, the human capital developed can benefit the organization even though it is "general."

The essence of feedback-seeking requires that employees, rather than an HR department or manager, own this activity by taking it upon themselves to solicit feedback and advice, and then translate it into an actionable plan for development. Employees diagnose skill needs and target ways to resolve those needs at their discretion. It enables employees to deal with increasingly complex tasks in a dynamic environment through repeated, regular feedback. This can help both the employer and employee to discover together in real-time what constitutes exemplary performance. This type of development can also help ameliorate the issues associated with flattened organizational structures. When organizations willingly respond to feedback-seeking requests with useful and supportive guidance it signals a commitment to the employee's career even in the absence of promotions or other formal signals. It also 
encourages a dialogue between the employee and the organization about how their role can evolve over time, enabling the employee to take on increasing responsibility even within a flat structure. Employees often respond with increased normative commitment (Meyer \& Allen, 1991), which constrains their willingness to explore labor market options post investment (Campbell et al., 2012; Saxton \& Dachner, 2016). This, in turn, allows the organization to better insure the value of investing in the employee through encouraging managers and peers to provide feedback and providing tools such as apps which facilitate feedback-seeking.

\subsection{Professional relationships}

Networking or engaging in a community of practice represent development activities that are autonomous and discretionary and require employees to put effort toward fostering relationships with other professionals to create growth opportunity. Networking refers to building and maintaining relationships with people, and then using those connections to access the knowledge and information needed to develop within one's role. Networking is an example of a social capital development behavior, defined as "activities of individuals aimed at developing relationships with others who have the potential to assist them in their careers" (Ng \& Feldman, 2010, p. 700). Theory and research suggest that people who network effectively become more central in their network and form stronger, positive social connections that provide access to informal advice and information (Klein, Lim, Saltz, \& Mayer, 2004; Leonardi, P., and N. Contractor, 2018). To assist individuals in the process of networking, professional organizations (e.g., SHRM, entrepreneur associations, and bar associations for attorneys) often host local networking events, Ted Talks, speaker series with successful professionals, and national and international conferences. These events provide opportunities for individuals to connect and build relationships with other professionals. Memberships in local professional groups or alumni clubs also provide some of the same networking opportunities.

Communities of practice refer to "informal [social] networks that support professional practitioners to develop a shared meaning and engage in knowledge building among the members" (Hara, 2000, p. 11). Dutton and Heaphy (2016) observed that "we rarely grow alone ... we only grow in connection with others." Communities of practice consist of employees who share similar professional interests but have a variety of different experiences. They vary in structure (e.g., how formal the group is regarding things like scheduling and documentation), format (e.g., whether conversations take place in person or using some form of technology), and intensity (e.g., whether the group is addressing an immediate concern), and some emerge organically through informal conversations that identify a shared interest among professionals or a common issue (e.g., book clubs).

Networking and communities of practice exemplify our broader conceptualization of employee development. Employees must proactively identify and engage in such opportunities, and are responsible for managing these professional connections. They can be encouraged to connect with and learn from others who have similar professional interests, but it is nearly impossible to force them to do so. Through communities and networks, employees share knowledge that aids not only with task/goal accomplishment but also with personal growth and professional career advancement (Ardichvilli, Page, \& Wentling, 2003; Brown \& Duguid, 1991; McFarland \& Ployhart, 2015). These activities provide a venue for learning tacit knowledge from peers and experts via increased communication and storytelling around problems or challenges with task execution (Kirkman, Mathieu, Cordery, Rosen, \& Kukenberger, 2011). This can provide crucial guidance when employees lack experience or are new to a role, or when the job context is rapidly changing. Communities and professional networks often leverage advanced technologies to facilitate this exchange. For example, employees can use personal devices to access experts via social media and receive regular updates on the latest expertise. Networks and communities also provide an opportunity for employees to increase organizational visibility within their current role, which can be important within a flattened hierarchy.

Social ties with colleagues from one's employer produce firm-specific human capital. The value created through those relationships will be difficult for employees to appropriate because the investment will degrade if the employee leaves the firm. In contrast, professional relationships forged outside and independent of an employer produce general human capital because the expertise gained is readily applicable to many firms. Employees are more likely to appropriate value from those relationships, particularly if those connections can be maintained (and even further strengthened) should the employee transition to a new employer. Most of the value created is embedded in the employee. However, studies suggests it may also create value for the employer, should the employee leave, through the building of social ties among company alumni networks (e.g., Carnahan \& Somaya, 2013).

\subsection{On-the-job experience}

Both job crafting and sabbaticals represent job experiences that involve employees proactively engaging in tasks and making changes to meet skill needs and fulfill personal career aspirations. Job crafting refers to a bottom-up approach to job design in which employees alter their work situation to achieve a better match between their needs/aspirations and circumstances/jobs (Wrzesniewski \& Dutton, 2001). Job crafting theory suggests that employees shape their work experiences by changing the behavioral, relational, and cognitive boundaries of their jobs (Wrzesniewski \& Dutton, 2001). They do so because of a desire to retain control, establish meaning, maintain a positive self-image, and forge connections to colleagues (Grant \& Parker, 2009), which allows them to identify more strongly with their work (Wrzesniewski \& Dutton, 2001). Based in McCauley, Ruderman, Ohlott, and Morrow (1994) which suggested that job design can influence employee development, two approaches to job crafting are particularly developmental. Task emphasizing involves employees electing to change the nature of a task or dedicate additional time and attention to a task. Job expanding involves finding and choosing to take on new, unknown tasks that often require the application of trial and error to accomplish (Berg, Grant, \& Johnson, 2010).

Sabbaticals refer to an employee being granted an extended period of time away from work to direct their attention toward 
personal and professional development (Zahorski, 1994). Although historically reserved for faculty in higher education (Iravania, 2011; Wildman, 2012), corporations are now recognizing their development advantages and offering sabbatical opportunities for employees as a part of their talent management strategy (Baruch \& Hall, 2004). About 23 of the Fortune 100 Best Companies to Work For offer fully or partially paid sabbaticals (Zimmerman, 2017). For example, Lockheed Martin Corporation has a sabbatical program that allows aspiring entrepreneurs to take unpaid leave to start a new business (Carr \& Tang, 2005), and Hilton offers employees a paid sabbatical opportunity to pursue a philanthropic project of their choice (Great Places to Work, 2018). Sabbaticals offer employees a chance to learn and develop through personally meaningful experiences or passion projects involving activities such as shadowing or working in an externship, participating in an international exchange program, or volunteering.

Job crafting and sabbaticals exemplify our broader conceptualization of employee development. Task emphasizing and job expanding involve employees taking the initiative to create opportunities to learn on their own within the realm of their job responsibilities. In this paradigm, employees exercise significant control over how, when, and in what form they pursue changes to their work experiences without having to wait for formal approval "up the chain". Job crafting may become especially important when work is done remotely or with limited social relationships. In general, job crafting generates firm-specific human capital because the knowledge and skills gained are idiosyncratic to the job being crafted and have little value on the larger labor market. This will enable the employer to capture most of the value generated from such investments. Moreover, potential gains in employee commitment from allowing flexibility in work responsibilities may also reduce the likelihood that the employee will leave the firm and allow the organization to further realize value. However, it is important to note that job crafting can also have negative consequences for employers that temper realized value when employees craft jobs in a way that supports personal growth but detracts from their colleagues well-being (Tims, Bakker, \& Derks, 2015) or employee productivity (Demerouti, Bakker, \& Halbesleben, 2015). Under such circumstances, the value appropriated by employers will be reduced as a function of the costs incurred by creating it.

Sabbaticals involves a similar creation of opportunities but the difference is learning and development takes place from experiences outside the organization, far beyond the typical boundaries of one's job. Sabbaticals enable employees to grow and develop both personally and professionally through transformation and experience, an essential component of lifelong learning (Passarelli \& Kolb, 2011). Although sabbaticals must be permitted by the organization, the developmental activities themselves can be identified by the employee personally or through corporate initiatives. Because such experiences demand an extraordinary level of commitment sabbaticals cannot be imposed on employees, rather they must be sought out, applied for, and preplanned proactively. The novel experiences that characterize sabbatical activities also permit the development of equally novel knowledge and skills through learning moments that offer authentic complexity and richness only made possible by learning within a literal context. This uniqueness, combined with the personally and socially-rewarding nature of the experience, implies that the value realized through these investments will typically be shared. Employees appropriates value associated with increased knowledge, skills, expertise, and character from their experiences. Organizations realize value through improved employee knowledge, communication, creative problem solving, and innovation (Dyer, 2002; Kramer, 2001). For example, manager evaluations of employees post-assignment confirm that employees are able to apply what they learned upon returning to their regular jobs after meaningful volunteer projects (Caligiuri, Mencin, \& Jiang, 2013). Moreover, employers benefit because employees often return from sabbaticals with increased attachment to the employer and renewed enthusiasm for the work (Carr \& Tang, 2005).

\section{Reflection}

Our goal in this review is to recommend a broader conceptualization of employee development that emphasizes a shared partnership approach. Most development research emphasizes the role of the organization, while most of the literature on employee learning (e.g., informal learning, lifelong learning, etc....) emphasizes the role of the individual. In reality, skill development and growth as a means for enhanced performance and career advancement result from the synthesis of organization and individual characteristics and investments (Billett, 2001; Rigolizzo, 2019).

Our choice to emphasize a shared partnership was deliberate, not only because the themes we articulate embody a perspective where both employee and organization have a meaningful role, but in recognition that calling for employees to be solely accountability for their own development has significant risks. For development activities to be effective and worthwhile, they must be informed by future task requirements and job options. Employees must have access to "insider" information concerning succession plans, promotion opportunities, market needs, near-term strategic goals, or anticipated changes in work design or structure. Since classic perspectives on employee development began with the employer's workforce needs, such information was naturally taken into account. A shared partnership provides a basis for gaining awareness about anticipated skill needs and growth opportunities, with employees taking the lead to seek and make use of this information.

Moreover, many contemporary employee development methods involve financial costs (e.g., fees, tuition, memberships, travel, etc....). Employees will be differentially able to afford those costs. A shared partnership perspective means employees and employers share the cost burden; or, that the employer covers the financial cost but expects employees to contribute time, social capital, or other personal resources to identify, pursue, and leverage development activities. In addition, making decisions about which methods to pursue is a risky and potentially costly endeavor when employees lack sufficient means for evaluating the quality of the development activity or the legitimacy of the knowledge source. Organizations need to act as partners in locating better quality development activities that address the right skill needs. For some methods this may be less of a concern (e.g., national certification exams), but for other methods (e.g., feedback-seeking) the quality of the activity has the potential to be highly variable.

Finally, a shared partnership helps ensure there are mechanisms in place to assist women, employees with disabilities, employees of lower socioeconomic status, and other minorities susceptible to discrimination in pursuing development. A solely accountable 
perspective can quickly devolve into systems of exclusion where access to the information and methods needed to be proactive in development are allocated based on ableism, sexism, elitism, or other forms of favoritism. Women and minorities face considerable barriers including limited access to the "right" job experiences, lack of mentoring, and little access to informal social networks (e.g., Cappelli, Hamori, \& Bonet, 2014; McDonald \& Westphal, 2013; Tharenou, 2001). With a partnership, organizations can operate as a growth resource for all employees. Critical information can flow through both formal and informal channels to help all employees diagnose skill needs and locate experiences, mentors, events, and educational opportunities to address those needs. In summary, we position organizations as supportive partners that can create opportunities for employees to develop through approaches such as job design or structured, social interaction (Billett, 2001, 2004), construct knowledge sharing systems that make content accessible, and provide a strong learning climate that enables, rewards, and facilitates employee growth (Janssens, Smet, Onghena, \& Kyndt, 2017).

\section{Future research agenda}

Scholarship has been slow to acknowledge that the classic theoretical notion of development as an organization-driven episode or intervention has become less relevant. In response, we hope this review provides a foundation for broadening the theoretical conversation around human capital development and stimulates scholarship with a more contemporary focus. Our review of past literature combined with examples within the four development categories highlight that practice has outpaced research. To spur scholarship forward, we outline a series of future research directions that embody our three recommendations.

We provided examples of proactive development behavior, but our list is not exhaustive. Future research is needed to identify the domain and occurrence patterns of proactive employee development behaviors. Qualitative studies that ask employees to describe how they develop themselves would be helpful in this regard. Further, studies should investigate the effectiveness of different types of proactive employee development. Certain development activities may be more effective, such that employees who gravitate toward these activities realize higher performance levels and experience greater career success. For example, taking the initiative to secure an industry certification may translate into better quality knowledge gained and more tangible career benefits such as a promotion, whereas completing a MOOC will develop skills and knowledge but subsequent effects on performance and career mobility may be indirect and more difficult to account for. Future research should also examine the cost savings associated with replacing various formal development initiatives with proactive development activities that are facilitated or emphasized by the organization but not explicitly delivered or managed by the organization (e.g., communities of practice, networking). Once the effectiveness and cost of various proactive development practices are examined, research can explore how employers might incentivize employees to make firm-specific investments.

The use of social media for development deserves research attention. For example, McFarland and Ployhart (2015) emphasize that social interaction occurs on a continuum of contexts including social media (e.g., Facebook, LinkedIn), face-to-face, and digital communications media (e.g., e-mail, text messaging). They propose eight specific discrete ambient stimuli (physicality, anonymity, permanence, accessibility, latency, interdependence, verifiability, and synchronicity) that distinguish social media from other contexts in which social interaction takes place. For example, social media allows individuals to share information with more people than in other contexts. The content posted has permanence which means it can be accessed at any time, but the level of expertise of the individual who provides the posting may be difficult to verify. This means there is a risk that information obtained from social media could be ineffective or harm performance. Another important question is how monitoring and verification influence how employees choose to use knowledge obtained through social media. For example, employees who acquire knowledge from unmonitored sites may defer applying it to work until it can be vetted. This may slow application of knowledge but enhance its effectiveness. Further, individual differences such as conscientiousness might influence the likelihood that employees take the time to verify information obtained through social media, while neuroticism affects the use of anonymity.

We need a better understanding of how the work environment can support and encourage proactive development behavior. Kahn's (1990) psychological engagement theory describes three conditions that may offer a useful starting point. Meaningfulness refers to a sense that one will receive a return on investment for his or her effort. Task characteristics, role characteristics, and work interactions help individuals feel valued which supports feelings of meaningfulness. Safety refers to being able to express one's self without fear of negative repercussions. It is enhanced when interpersonal relationships, group dynamics, management styles, and norms are perceived to be trustworthy, secure, and predictable. Availability refers to possessing the physical, cognitive, and psychological resources that one needs in order to invest in on-the-job activities.

Factors such as an individual's work-life balance, the quality of one's relationships with managers, and job characteristics likely influence availability, safety, and meaningfulness. Tews, Noe, Scheurer, and Michel (2016) found that conflict due to time-based work-interference with family had a negative relationship with informal learning. Compared to formal organization-driven development, employee-driven development is likely to occur more frequently outside of work (e.g., taking a MOOC, attending a professional society meeting in the evening hours) which forces this type of development to compete for resources ordinarily allocated toward family or personal responsibilities and leisure time. Walumbwa, Cropanzano, and Hartnell (2009) found that employees with a high-quality, leader-member exchange relationship with their supervisor engaged in more voluntary performance improvement behaviors. This suggests that safe relationships with managers may encourage individuals to step out of their comfort zones and participate in new or novel development activities (e.g., volunteering) even if such involvement could lead to failure or embarrassment. In addition, job autonomy, or the degree to which a job gives an employee freedom, independence, and discretion in completing job responsibilities (Hackman \& Oldham, 1976), may enable feelings of meaningfulness, which would in turn support proactive development. Several studies show that job autonomy is more responsible than any other job characteristic for providing individuals with the opportunity to learn (see review by Parker, 2014). 
The recognition that combining general human capital with firm-specific assets can produce a competitive advantage from the unique complementarity that results (Chadwick, 2017) suggests that understanding the nature and properties of these complementarities is another important area for future research. These complementarities may involve particular human resource practices that create constraints on employee mobility or otherwise produce frictions in the labor market (Campbell et al., 2012; Delery \& Roumpi, 2017; Saxton \& Dachner, 2016). Alternatively, there may be low cost structures for managing idiosyncratic bundles of human capital. A firm that has a lower "human resources overhead" than its rivals will generate more value from the same general human capital than its rivals do (Chadwick, 2017). Employee-driven development practices introduce the possibility for both of these effects.

Finally, much of what we know about employee development is based on research conducted with traditional full-time employees. We know little about development for employees who are working in the increasingly popular "gig" economy or other alternative employment relationships. For example, for contract workers, development and career progression likely occurs solely through "stretchwork" assignments that capitalize on their current competence and motivate them to learn new things (O'Mahony \& Bechky, 2006). One of the challenges in developing contract workers is insuring that the type and length of their development opportunities are sufficient for increasing their skills, but not so extensive that it qualifies them legally as full-time employees for salary and benefit purposes (Kuzel, 2018). Research needs to examine how these types of employees pursue proactive development within the context of non-traditional work.

\section{Conclusion}

Today's work environment necessitates a broader conceptualization of employee development that includes employee-driven development. Human capital development is as important as ever for both employers and employees. Organizations can better manage human capital by leveraging the various ways through which employees proactively develop themselves as a strategic supplement to formal training and development practices. Proactive development practices provide a means for firms to invest in human capital to enhance firm performance while minimizing potential risks; a cost-sharing perspective that represents a win-win situation for both the employee and the employer. Note that we are not suggesting that traditional, organization-initiated employee development practices have no place in human capital development today. Rather, our goal in this review has been to emphasize that now is the time for scholars to acknowledge an expanded domain of development activities, and integrate employee-driven development into traditional development theory. By following our recommendations for advancing employee development research and practice, studies of employee development will be poised to provide further theoretical insights concerning what development is, how it occurs, and its value.

\section{References}

Deloitte (2017). Rewriting the rules for the digital age: 2017 Deloitte global human capital trends. Retrieved from https://www2.deloitte.com/content/dam/Deloitte/ global/Documents/HumanCapital/hc-2017-global-human-capital-trends-gx.pdf.

Great Places to Work (2018). World's best workplaces. available at https://www.greatplacetowork.com/best-workplaces/worldsbest/2018/hilton-worldwide, Accessed date: 1 October 2019.

Allen, D. T., Eby, L. T., Chao, G. T., \& Bauer, T. N. (2017). Taking stock of two relational aspects of organizational life: Tracing the history and shaping the future of socialization and mentoring research. Journal of Applied Psychology, 102(3), 324-337.

Allen, T., Eby, L., Poteet, M., Lentz, E., \& Lima, L. (2004). Career benefits associated with mentoring for protégés: A meta-analysis. Journal of Applied Psychology, 89, $127-136$.

Antonacopoulou, E. P. (2000). Employee development through self-development in three retail banks. Personnel Review, $29(4), 491$.

Ardichvilli, A., Page, V., \& Wentling, T. (2003). Motivation and barriers to participation in virtual knowledge sharing in communities of practice. Journal of Knowledge Management, 7(1), 64-77.

Ashford, S. J., \& Cummings, L. L. (1983). Feedback as an individual resource: Personal strategies of creating information. Organizational Behavior and Human Performance, 32, 370-398.

Association for Talent Development (2016). 2016 Association for Talent Development State of the Industry Report. Retrieved from https://www.td.org/ProfessionalResources/State-Of-The-Industry-Report.

Baldwin, T., \& Ford, J. K. (1988). Transfer of training: A review and directions for future research. Personnel Psychology, 41, 63-105.

Bandura, A. (1977). Social Learning Theory. Englewood Cliffs, N.J: Prentice-Hall.

Barnes, N. G., Lescault, A. M., \& Wright, S. (2013). Fortune 500 are bullish on social media: Big companies get excited about Google +, Instagram, foursquare, \& Pinterest. University of Massachusetts Dartmouth Center for Marketing Research.

Barney, J. B., \& Wright, P. M. (1998). On becoming a strategic partner: The role of human resources in gaining competitive advantage. Human Resource Management, $37(1), 31-46$.

Baruch, Y., \& Hall, D. T. (2004). The academic career: A model for future careers in other sectors? Journal of Vocational Behavior, 64(2), 241-262.

Bateman, T., \& Crant, J. (1993). The proactive component of organizational behavior: A measure and correlates. Journal of Organizational Behavior, 14, 103-118.

Becker, G. S. (1964). Human capital: a theoretical and empirical analysis, with special reference to education. New York: National Bureau of Economic Research; distributed by Columbia University Press.

Bedwell, W. L., Weaver, S. J., Salas, E., \& Tindall, M. (2011). Emerging conceptualizations of adult training and learning. In M. London (Ed.). The Oxford handbook of lifelong learning (pp. 450-471). Oxford: Oxford University Press.

Belkin, D. (2014). Former Yale president to lead Coursera. Wall Street JournalB3.

Bell, B. S., Tannenbaum, S. I., Ford, J. K., Noe, R. A., \& Kraiger, K. (2017). 100 years of training and development research: What we know and where should we go. Journal of Applied Psychology, 102(3), 305-323.

Berg, J. M., Grant, A. M., \& Johnson, V. (2010). When callings are calling: Crafting work and leisure in pursuit of unanswered occupational callings. Organization Science, 21, 973-994.

Bersin, J. (2015, August 26). Feedback is the killer app: A new market and management model emerges. Retrieved from https://www.forbes.com/sites/joshbersin/ 2015/08/26/employee-feedback-is-the-killer-app-a-new-market-emerges/\#7cdff39f5edf.

Billett, S. (2001). Learning through work: Workplace affordances and individual engagement. Journal of Workplace Learning, 13, $209-214$.

Billett, S. (2004). Workplace participartoy practices: Conceptualising workplaces as learning environments. Journal of workplace Learning, $16(6), 312-324$. 
Brown, J. S., Collins, A., \& Duguid, P. (1989). Situated cognition and the culture of learning. Educational Research, 18, 32-42.

Brown, J. S., \& Duguid, P. (1991). Organizational learning and communities of practice: Toward a unified view of working, learning, and innovation. Organization Science, 2, 40-57.

Cabrera, E. F. (2007). Opting out and opting in: Understanding the complexities of women's career transitions. Career Development International, 12 (3), $218-237$.

Caligiuri, P., Mencin, A., \& Jiang, K. (2013). Win-win-win: The influence of company-sponsored volunteerism programs on employees, NGOs, and business units. Personnel Psychology, 66, 825-860.

Campbell, B. A., Coff, R., \& Kryscynski, D. (2012). Rethinking sustained competitive advantage from human capital. Academy of Management Review, 37(3), 376-395. Campbell, B. A., Saxton, B. M., \& Banerjee, P. M. (2014). Resetting the shot clock: The effect of comobility on human capital. Journal of Management, 40(2), 531-556. Cappelli, P. (1999). The new Deal at work. Boston: MA: Harvard Business Press.

Cappelli, P. (2008). Talent on demand: Managing talent in an age of uncertainty. Boston: MA: Harvard Business Press.

Cappelli, P., Hamori, M., \& Bonet, R. (2014). Who's got those top jobs? Harvard Business Review, 92(3), 74-77.

Carnahan, S., \& Somaya, D. (2013). Alumni effects and relational advantage: The impact on outsourcing when a buyer hires employees from a supplier's competitors. Academy of Management Journal, 56(6), 1578-1600.

Carr, A. E., \& Tang, T. L. P. (2005). Sabbaticals and employee motivation: Benefits, concerns, and implications. Journal of Education for Business, 80(3), 160-164.

Cascio, W. F. (2014). Leveraging employer branding, performance management, and human resource development to enhance employee retention. Human Resource Development International, 17(2), 121-128.

Cerasoli, C. P., Alliger, G. M., Donsbach, J. S., Mathieu, J. E., Tannenbaum, S. I., \& Orvis, K. A. (2018). Antecedents and outcomes of informal learning behaviors: A meta-analysis. Journal of Business and Psychology, 33(2), 203-230.

Chadwick, C. (2017). Toward a more comprehensive model of firms' human capital rents. Academy of Management Review, 15(3), $200-213$.

Chen, G., \& Klimoski, R. J. (2007). Training and development of human resources at work: Is the state of our science strong? Human Resource Management Review, 17, $180-190$.

Coff, R., \& Kryscynski, D. (2011). Invited editorial: Drilling for micro-foundations of human capital-based competitive advantages. Journal of Management, 37(5), $1429-1443$.

Courtright, S. H., Colbert, A. E., \& Choi, D. (2014). Fired up or burned out? How developmental challenge differentially impacts leader behavior. Journal of Applied Psychology, 99(4), 681-696.

Crant, J. M. (2000). Proactive behavior in organizations. Journal of Management, 26, 435-462.

Delery, J. E., \& Roumpi, R. (2017). Strategic human resource management, human capital and competitive advantage: Is the field doing in circles? Human Resource Management Journal, 27(1), 1-21.

Demerouti, E., Bakker, A. B., \& Halbesleben, J. R. B. (2015). Productive and counterproductive job crafting: A daily diary study. Journal of Occupational Health Psychology, 20(4), 457-469.

DeRue, D. S., Ashford, S. J., \& Myers, C. G. (2012). Learning agility: In search of conceptual clarity and theoretical grounding. Industrial and Organizational Psychology, (3), 258-279.

Donovan, J., \& Benko, C. (2016). AT\&T's talent overhaul. Harvard Business Review, 68-73.

Dragoni, L., Oh, I.-S., Vankatwyk, P., \& Tesluk, P. E. (2011). Developing executive leaders: The relative contribution of cognitive ability, personality, and the accumulation of work experience in predicting strategic thinking competency. Personnel Psychology, 64(4), 829-864.

Dutton, J. E., \& Heaphy, E. (2016). We learn more when we learn together. Harvard Business Review.

Dweck, C. S. (1986). Motivational processes affecting learning. American Psychologist, 41, 1040-1048.

Dweck, C. S. (1989). Motivation. In A. Lesgold, \& R. Glaser (Eds.). Foundations for psychology of education (pp. 87-136). Mahwah, NJ: Erlbaum.

Dyer, M. (2002). Time out: Taking a sabbatical can be beneficial for staff and employers alike. Employees can use the time to unwind or update their skills, while companies stand to gain happier and more committed staff. Microscope, 21(11), 43-44.

Eby, L. T., Butts, M. M., Hoffman, B. J., \& Sauer, J. B. (2015). Crosslagged relations between mentoring received from supervisors and employee OCBs: Disentangling causal direction and identifying boundary conditions. Journal of Applied Psychology, 100, 1275-1285.

Ellström, P. E. (2001). Integrating learning and work: Problems and prospects. Human Resource Development Quarterly, 12(4), 421-435.

Fowler, G. (2013a). An early report card on MOOCs. Wall Street Journal, R1-R2.

Fowler, G. (2013b). Most online course users well-educated. Wall Street Journal, A3.

Fugate, M., Kinicki, A. J., \& Ashforth, B. E. (2004). Employability: A psycho-social construct, its dimensions, and applications. Journal of Vocational Behavior, 65, $14-38$.

Gagne, R. M. (1962). Psychological principles in system development. New York: Holt, Rinehart and Winston, Inc.

Garofano, C. M., \& Salas, E. (2005). What influences continuous employee development decisions? Human Resource Management Review, 15, $281-304$.

Goldstein, I. L. (1986). Training in organizations: Needs assessment, development, and evaluation. Monterey, CA: Brooks/Cole Publishing Company.

Gowan, M. A. (2012). Employability, well-being, and job satisfaction following a job loss. Journal of Managerial Psychology, 27(8), 780-798.

Grant, A. M., \& Parker, S. K. (2009). 7 redesigning work design theories- the rise of relational and proactive perspectives. Academy of Management Annals, 3(1), 317-375.

Griffin, M. A., Neal, A., \& Parker, S. K. (2007). A new model of work role performance: Positive behavior in uncertain and interdependent contexts. Academy of Management Journal, 50(2), 327-347.

Groysberg, B., Lee, L. E., \& Nanda, A. (2008). Can they take it with them? The portability of star knowledge workers' performance. Management Science, 54(7), 1213-1230.

Hackman, J. R., \& Oldham, G. R. (1976). Motivation through the design of work: Test of a theory. Organizational Behavior and Human Performance, 16 (250-245).

Hamori, M. (January-February 2018). Can MOOCs solve your training problem? Harvard Business Review, 70-77.

Hara, N. (2000). Social construction of knowledge in professional communities of practice: Tales in courtrooms. Unpublished doctoral dissertationBloomington: Indiana University.

Harris, P. (2015). Serving up innovation. TD: Talent. Development, 69(11), 80-82.

Harrison, D. A., Johns, G., \& Martocchio, J. J. (2000). Changes in technology, teamwork, and diversity: New directions for a new century of absenteeism research. In G. Ferris (Vol. Ed.), Research in personnel and human resources management. Vol. 18. Research in personnel and human resources management (pp. 43-91). Greenwich, CT: JAI Press.

Huckman, R. S., \& Pisano, G. P. (2006). The firm specificity of individual performance: Evidence from cardiac surgery. Management Science, 52(4), 473-488.

Hurtz, G., \& Williams, K. (2009). Attitudinal and motivational antecedents of participation in voluntary employee development activities. Journal of Applied Psychology, 94, 635-653.

Iravania, H. (2011). Analyzing impacts of sabbatical leaves of absence regarding faculty members. Procedia-Social and Behavioral Sciences, 15, $3608-3615$.

Jacobs, R. L., \& Park, Y. (2009). A proposed conceptual framework of workplace learning: Implications for theory development and research in human resource development. Human Resource Development Review, 8(2), 133-150.

Janssens, L., Smet, K., Onghena, P., \& Kyndt, E. (2017). The relationship between learning conditions in the workplace and informal learning outcomes: A study among police inspectors. International Journal of Training and Development, 21(2), 92-112.

Jehanzeb, K., \& Mohanty, J. (2018). Impact of employee development on job satisfaction and organizational commitment: Person-organization fit as moderator. International Journal of Training and Development, 22(3), 171-191.

Kahn, W. A. (1990). Psychological conditions of personal engagement and disengagement at work. Academy of Management Journal, $33,692-724$.

Fuller, J., Jr., Kester, K., \& Cox, S. S. (2010). Proactive personality and job performance: Exploring job autonomy as a moderator. Journal of Managerial Issues, 22(1), 35-51.

Kirkman, B. L., Mathieu, J. E., Cordery, J. L., Rosen, B., \& Kukenberger, M. (2011). Managing a new collaborative entity in business organizations: Understanding 
organizational communities of practice effectiveness. Journal of Applied Psychology, 96, 1234-1245.

Klein, B., Crawford, R. G., \& Alchian, A. A. (1978). Vertical integration, appropriable rents, and the competitive contracting process. Journal of Law and Economics, 21(2), 297-326.

Klein, K. J., Lim, B.-C., Saltz, J. L., \& Mayer, D. M. (2004). How do they get there? An examination of the antecedents of centrality in team networks. Academy of Management Journal, 47(6), 952-963.

Kramer, Daniel C. (2001). Workplace Sabbaticals: Bonus or Entitlement? CT:Quorum: Wesport.

Kraiger, K. (2008). Transforming our models of learning and development: Web-based instruction as enabler of third-generation instruction. Industrial and Organizational Psychology, 1(4), 454-457.

Kraiger, K., \& Ford, J. K. (2007). The expanding role of workplace training: Themes and trends influencing training research and practice. In L. L. Koppes (Ed.). Historical perspectives in industrial and organizational psychology (pp. 281-309). Mahwah, NJ: Erlbaum.

Kuzel, A. (2018). Learning and the flexible workforce, chief learning officer (January/February 2018): 32-35.

Lazear, E. P. (2009). Firm-specific human capital: A skill-weights approach. Journal of Political Economy, 117(5), 914-940.

Lee, E. (2014). Online courses trim billions in personnel training. Retrieved from http://www.cnbc.com/2014/02/13/online-courses-trim-billions-in-personneltraining.html.

Leonardi, P. \& N. Contractor (2018). Better People Analytics. Harvard Business Review, 70-81.

London, M. (2011). Lifelong learning: Introduction. In M. London (Ed.). The Oxford handbook of lifelong learning (pp. 450-471). Oxford: Oxford University Press.

Luthans, F., Youssef, C. M., \& Avolio, B. J. (2007). Psychological capital: Developing the human competitive edge. Oxford University Press.

Major, D. A., Turner, J. E., \& Fletcher, T. D. (2006). Linking proactive personality and the big five to motivation to learn and development activity. Journal of Applied Psychology, 91(4), 927-935.

Maxey, L. (2017). An investment in MOOCs pays off in talent. Chief Learning Officer, 16.

McCall, M. W. (2004). Leadership development through experience. Academy of Management Executive, 18, $127-130$.

McCauley, C. D., \& Hezlett, S. A. (2001). Individual development in the workplace. In N. Anderson, D. S. Ones, H. K. Sinangil, \& C. Viswesvaran (Eds.). Handbook of industrial, work \& organizational psychology (pp. 313-335). London: Sage Publications.

McCauley, C., Ruderman, M., Ohlott, P., \& Morrow, J. (1994). Assessing the developmental components of managerial jobs. Journal of Applied Psychology, 79, 544-560.

McDonald, M. L., \& Westphal, J. D. (2013). Access denied: Low mentoring of women and minority first-time directors and its negative effects on appointments to additional boards. Academy of Management Journal, 56(4), 1169-1198.

McFarland, L. A., \& Ployhart, R. E. (2015). Social media: A contextual framework to guide research and practice. Journal of Applied Psychology, 100(6), 1653-1677.

Meyer, J. P., \& Allen, N. J. (1991). A three-component conceptualization of organizational commitment. Human Resource Management Review, 1, 61-89.

Mohrman, S. A., Cohen, S. G., \& Mohrman, A. M., Jr. (1995). Designing team-based organization: New forms for knowledge work. San Fransisco: Josey-Bass.

Molloy, J. C., \& Noe, R. A. (2010). "Learning" a living: Continuous learning for survival in today's talent market. In S. W. J. Kozlowski, \& E. Salas (Eds.). Learning, training, and development in organizations (pp. 333-361). New York: Routledge.

Morris, S., Alvarez, S. A., Barney, J. B., \& Molloy, J. C. (2017). Firm-specific human capital investments as a signal of general value: Revisiting assumptions about human capital and how it is managed. Strategic Management Journal, 38(4), 912-919.

Morrison, R. F., \& Brantner, T. M. (1992). What enhances or inhibits learning a new job? A basic career issue. Journal of Applied Psychology, 77, 926-940.

Newton, D. (2018). December 16. Please stop asking whether college is worth it. Retrieved from https://www.forbes.com/sites/dereknewton/2018/12/16/please-stopasking-whether-college-is-worth-it/\#398e182330d2.

Ng, T., \& Feldman, D. C. (2010). The effects of organizational embeddedness on development of social capital and human capital. Journal of Applied Psychology, 95(4), 696-712.

Noe, R. A. (2017). Employee training \& development (7th ed.). Burr Ridge, IL: McGraw-Hill.

Noe, R. A., Clarke, A. D. M., \& Klein, H. J. (2014). Learning in the twenty-first-century workplace. Annual Review of Organizational Psychology and Organizational Behavior, 1, 245-275.

Noe, R. A., Wilk, S. L., Mullen, E. J., \& Wanek, J. E. (1997). Employee development: Issues in construct definition and investigation of antecedents. In E. A. Fleishman, \& J. K. Ford (Eds.). Improving training effectiveness in work organizations (pp. 153-189). Mahwah, NJ: Erlbaum.

O'Mahony, S., \& Bechky, B. A. (2006). Stretchwork: Managing the career progression paradox in external labor markets. Academy of Management Journal, 49(5), 918-941.

Parker, S. K. (2014). Beyond motivation: Job and work design for development, health, ambidexterity, and more. Annual Review of Psychology, 65, 661-691.

Parker, S. K. (2017). Work design growth model: How work characteristics promote learning and development. In J. E. Ellingson, \& R. A. Noe (Eds.). Autonomous learning in the workplace (pp. 137-161). New York, NY: Taylor \& Francis.

Parker, S. K., Bindl, U. K., \& Strauss, K. (2010). Making things happen: A model of proactive motivation. Journal of Management, 36, 827-856.

Parker, S. K., \& Collins, C. G. (2010). Taking stock: Integrating and differentiating multiple proactive behaviors. Journal of Management, 36(3), 633-662.

Parker, S. K., Williams, H. M., \& Turner, N. (2006). Modeling the antecedents of proactive behavior. Journal of Applied Psychology, 91, 636-652.

Passarelli, A., \& Kolb, D. (2011). The learning way: Learning from experience as the path to lifelong learning and development. In M. London (Ed.). The Oxford handbook of lifelong learning. Oxford: Oxford University Press.

Payne, S., \& Huffman, A. (2005). A longitudinal examination of the influence of mentoring on organizational commitment and turnover. Academy of Management Journal, 48, 158-168.

Ployhart, R. E., Nyberg, A. J., Reilly, G., \& Maltarich, M. A. (2014). Human capital is dead; long live human capital resources!. Journal of Management, 40(2), 371-398.

Pricewaterhouse Coopers LLP (2016). 20th annual global CEO survey. Retrieved from http://www.pwc.com/gx/en/ceo-survey/2017/pwc-ceo-20th-survey-report2017.pdf.

Ravenscroft, A., Schmidt, A., Cook, J., \& Bradley, C. (2012). Designing social media for informal learning and knowledge maturing in the digital workplace. Journal of Computer Assisted Learning, 28(3), 235-249.

Reinhardt, W., Schmidt, B., Sloep, P., \& Drachsler, H. (2011). Knowledge worker roles and actions: Results of two empirical studies. Knowledge and Process Management, $18(3), 150-174$.

Rigolizzo, M. (2019). Ready and willing to learn: Exploring personal antecedents to taking on learning challenges. Journal of Workplace Learning, 31(4), 289-304.

Romiszowski, A., \& Mason, R. (2004). Computer-mediated communication. In D. H. Jonassen (Ed.). Handbook of research for educational communications and technology (pp. 397-431). (2nd ed.). New York: Simon \& Schuster Macmillan.

Rousseau, D. (1995). Psychological contracts in organizations. Thousand Oaks, CA: Sage Publications.

Ruppel Shell, E. (2018, May 16). College may not be worth it anymore. Retrieved from https://www.nytimes.com/2018/05/16/opinion/college-useful-cost-jobs.html.

Salopek, J. (2015). Creating the engineers of tomorrow, today. Talent Development, 69(11), 57-58.

Saxton, B. M., \& Dachner, A. M. (2016). Toward a theory of supply-side mobility constraints: Assessing value creation and value capture. Presentation at The Academy of Management Annual Conference: Anaheim, CA.

Schawbel, D. (2012). How job hopping can hurt your career. Retrieved from http://edition.cnn.com/2012/01/17/opinion/job-hopping-schawbel/index.html.

Schmidt, A. M., \& Ford, J. K. (2003). Learning within a learner control training environment: The interactive effects of goal orientation and metacognitive instruction on learning outcomes. Personnel Psychology, 56(2), 405-429.

Seibert, S. E., Kraimer, M. L., \& Crant, J. M. (2001). What do proactive people do? A longitudinal model linking proactive personality and career success. Personnel Psychology, 54, 845-874.

Seiling, J. G. (2001). The meaning and role of organizational advocacy: Responsibility and accountability in the workplace. Westport, CT: Quorum Books.

Sitzmann, T. M., Kraiger, K., Stewart, D. W., \& Wisher, R. A. (2006). The comparative effectiveness of web-based and classroom instruction: A meta-analysis. Personnel Psychology, 59(3), 623-664.

Skinner, B. F. (1953). Science and human behavior. New York: Macmillan. 
Smither, J. W., \& Walker, A. G. (2004). Are the characteristics of narrative comments related to improvement in multirater feedback over time? Journal of Applied Psychology, 89, 575-581.

Society for Human Resource Management (2009). Future insights: The top trends according to SHRM's HR subject matter expert panels. Alexandria, VA.

Society for Human Resource Management (2012). Future insights: The top trends according to SHRM's HR subject matter expert panels. Alexandria, VA.

Society for Human Resource Management (2015). Business and human capital challenges today and in the future. Alexandria, VA.

Sullivan, S., \& Baruch, Y. (2009). Advances in career theory and research: A critical review and agenda for future exploration. Journal of Management, 35(6), $1542-1571$.

Tannenbaum, S. I., Beard, R., McNall, L. A., \& Salas, E. (2010). Informal learning and development in organizations. In S. W. J. Kozlowski, \& E. Salas (Eds.). Learning, training, and development in organizations (pp. 303-332). New York, NY: Routledge.

Telford, B. N., Fletcher, K. A., \& Bedwell, W. L. (2017). Informal learning in the healthcare industry. In J. E. Ellingson, \& R. A. Noe (Eds.). Autonomous learning in the workplace (pp. 219-236). New York, NY: Taylor \& Francis.

Tews, M. J., Noe, R. A., Scheurer, A. J., \& Michel, J. W. (2016). The relationships of work-family conflict and core self-evaluations with informal learning in a managerial context. Journal of Occupational and Organizational Psychology, 89(1), 92-110.

Tharenou, P. (2001). Going up? Do traits and informal social processes predict advancing in management? Academy of Management Journal, 44(5), 1005-1017.

Tharp, D. (2018, February 15). Is a college degree worth it? The answer isn't as simple as you think. Retrieved from https://blogs.wsj.com/experts/2018/02/15/is-acollege-degree-worth-it-the-answer-isnt-as-simple-as-you-think/.

Thomas, J. (2015). At EAG, learning's all about the chatter. Chief Learning Officer, 42-43, 49.

Thompson, J. A. (2005). Proactive personality and job performance: A social capital perspective. Journal of Applied Psychology, 90(5), $1011-1017$.

Tims, M., Bakker, A. B., \& Derks, D. (2015). Examining job crafting from an interpersonal perspective: Is employee job crafting related to the well-being of colleagues? Applied Psychology, 64(4), 727-753.

Walumbwa, F. O., Cropanzano, R., \& Hartnell, C. A. (2009). Organizational justice, voluntary learning behavior, and job performance: A test of the mediating effects of identification and leader-member exchange. Journal of Organizational Behavior, 30(8), 1103-1126.

Wang, S., \& Hsu, H. (2008). Use of the webinar tool (Elluminate) to support training: The effects of webinar-learning implementation from student-trainers' perspective. Journal of Interactive Online Learning, 7(3), 175-194.

Wildman, K. L. (2012). Staff sabbaticals: an examination of sabbatical purposes and benefits for higher education administrators. dissertation Iowa City, IA: University of Iowa. available at: http://ir.uiowa.edu.jcu.ohionet.org/etd/3009, Accessed date: 1 October 2019.

Wrzesniewski, A., \& Dutton, J. E. (2001). Crafting a job: Revisioning employees as active crafters of their work. Academy of Management Review, 26(2), 179-201.

Zahorski, K. J. (1994). The sabbatical mentor: A practical guide to successful sabbaticals. Boston, MA: Anker Publishing.

Zimmerman, K. (2017). This underrated employee benefit is helping American workers recharge' December 10. from www.forbes.com, Accessed date: 6 November 2019. 